\title{
Cholinesterase Activity in the Head of Wild Poecilia reticulata from Bahia, Brazil: Biochemical Characterization, Effects of Sample Storage and Normal Range of Activity
}

\author{
C. Stringuetti, ${ }^{1}$ L. Guilhermino ${ }^{2}$ \& E. M. Da Silva ${ }^{1 *}$ \\ ${ }^{1}$ Institute of Biology, UFBA, Campus de Ondina, CEP 40170-115, Salvador, BA, Brazil \\ ${ }^{2}$ Centro Interdisciplinar de Investigação Marinha e Ambiental (CIMAR), Rua dos Bragas, 177, CEP 4050-123, Porto,
}

Portugal (Received July 25, 2007; Accepted May 13, 2008)

\begin{abstract}
In this study, the soluble cholinesterases (ChE) from the head of Poecilia reticulata from a wild population of Bahia, Brazil were characterized using different substrates (acetylthiocoline, butyrylthiocoline and proprionylthiocoline) and selective inhibitors (eserine sulphate, iso-OMPA and BW284C51). Possible effects of time (1, 2, 3, and 4 weeks) and different storage temperatures (freezer storage at $c a .-20^{\circ} \mathrm{C}$ and $-50^{\circ} \mathrm{C}$, and liquid nitrogen system at $-196^{\circ} \mathrm{C}$ ) on $\mathrm{ChE}$ activity were also investigated, together with the normal range of $\mathrm{ChE}$ activity of non-exposed individuals. The results for the enzymatic characterization indicate that the enzyme present in the head of $P$. reticulata was mainly acetylcholinesterase. The mean and standard deviation of activity found in non-exposed wild males collected in different periods of the year were $149.71 \pm 7.72$ SD U/mg protein, respectively. ChE activity significantly decreased after the seventh day of sample storage, independently of the temperature.
\end{abstract}

Key words: biomarker, cholinesterase, Poecilia reticulata, sample storage conditions.

\section{RESUMO}

Atividade da colinesterase na cabeça de indivíduos selvagens de Poecilia reticulata (Bahia, Brasil): caracterização bioquímica, efeitos sobre armazenamento de amostras e atividade normal

Neste estudo foram caracterizadas as colinesterases solúveis (ChE) da cabeça de uma população selvagem de Poecilia reticulata do Estado da Bahia (Brasil) usando-se diferentes substratos (acetil-tiocolina, butiril-tiocolina e propionil-tiocolina) e seus inibidores seletivos (sulfato de eserina, iso-OMPA e BW284C51). Efeitos resultantes do armazenamento (1, 2, 3 e 4 semanas) e de diferentes temperaturas de armazenamento (em congelador $c a .-20^{\circ} \mathrm{C}$ e $-50^{\circ} \mathrm{C}$, e em imersão em nitrogênio líqui-do, $c a .-196^{\circ} \mathrm{C}$ ) sobre a atividade enzimática da $\mathrm{ChE}$ foram também investigados, junto com a atividade enzimática normal de indivíduos não expostos. $\mathrm{A}$ média e o desvio-padrão da atividade normal de indivíduos machos não expostos e coletados periodicamente do campo foram de $149,71 \pm 7,72$ DP U/mg protein, respectivamente. Os resultados para a caracterização enzimática indicam que a enzima presente na cabeça de $P$. reticulata foi, majoritariamente, a acetio-colinesterase. A atividade enzimática decresceu significativamente após o sétimo dia de armazenamento, independente da temperatura.

Palavras-chave: biomarcador, colinesterase, Poecilia reticulata, condições de armazenamento das amostras.

*Corresponding author: Eduardo Mendes da Silva, e-mail: dasilva@ufba.br. 


\section{INTRODUCTION}

The inhibition of cholinesterase (ChE) activity has been largely used to diagnose the exposure of wild populations to anticholinesterase chemicals such as organophosphates and carbamate pesticides (Ozmen et al., 1999; Fossi et al., 2001; Fulton \& Key, 2001). Usually cholinesterases are divided in acetylcholinesterase (AChE) and pseudocholinesterase or butyrylcholinesterase (PChE) (Fossi \& Leonzio, 1994), according to their behaviour towards different substrates and selective inhibitors (Stojan et al., 1998). Typical AChEs, such as mammalian ones, show preference for acetylthiocholine as substrate, relatively to butyrylthiocholine and propionylthiocholine, are strongly inhibited by low concentrations of BW284C51 and show low sensitivity to N,N'-diisipropylphosphorodiamic acid (Iso-OMPA) (Eto, 1974). Since different forms of ChE may have different sensitivity to anticholinesterasic contaminants and this may be a source of variation in ecotoxicological studies (Galgani \& Bocquené, 1990; Garcia et al., 2000), it is important to characterise the forms present in the population and in the tissues of the organisms to be studied before using these enzymes as biomarker (Garcia et al., 2000). This is particularly important in biomonitoring programs with wild populations.

When dealing with a high number of samples, frequently it is not possible to perform $\mathrm{ChE}$ determinations immediately after the tissue isolation and they need to be stored before being analysed. Several authors report a significant decrease of ChE activity in samples of different species frozen for more than two weeks (Galgani \& Bocquené, 1990; Day \& Scott, 1990) while others did not found significant differences between fresh and frozen samples (Guilhermino et al., 1996b). Since this variation may be species dependent and due to its importance, it is recommendable to choose the appropriated method and temperature of storage before performing $\mathrm{ChE}$ based studies requiring storage of samples.

Poecilia reticulata is an abundant species in Brazilian freshwater systems and since it is a recommended organism for aquatic toxicity testing in international protocols (OECD, 1993) it seems to be a good candidate to be used as bioindicator in biomonitoring studies. Therefore, the central objective of this work was to establish the basic conditions required for the use of wild $P$. reticulata populations to assess environmental contamination of freshwater ecosystems in Bahia (Brazil), by anticholinesterase pesticides. Specifically, the objectives of this work were: i) to perform the biochemical characterization of the soluble $\mathrm{ChE}$ present in wild $P$. reticulata head homogenates, (ii) to investigate the effects of time and temperature of preservation on ChE activity, and (iii) to determine the range of normal activity in fish from wild populations.

\section{MATERIALS AND METHODS}

\section{Fish}

Adult male fish (1.8-2.7 cm long) were collected from a noncontaminated site from the Capivari Creek (Cruz das Almas, BA, Brazil) and transported to laboratory in low density in $20 \mathrm{~L}$ plastic containers to minimise stress. Organisms were held in 10-L flow-through aquaria containing natural glass-fibre filtered water from the collection site with approximately 20 individuals per tank, and fed ad libitum, once a day, with live cladocerans, supplemented with dried fish food (Alcon Basic). Vessels were cleaned and debris removed via vacuum suction every $2 \mathrm{~d}$. They were acclimated to a temperature of $26 \pm 2^{\circ} \mathrm{C}$ and a photoperiod of $16: 8 \mathrm{~h}$ light:dark periods, for at least 5 days in the laboratory prior to test initiation. The general health of the animals appeared good, and no evidence of fungal infection was observed during this period. In all experiments, adequate measures were taken to minimise pain or discomfort and animals were handled according to the recommendation of Baumans (2005).

\section{Homogenate preparation}

The basic procedure of Frasco \& Guilhermino (2002) was carried out for the homogenisation of the biological matrix. Eighteen fish were collected from the aquarium and sacrificed by decapitation. The head without gills and any vestige of blood was transferred to a test tube containing $1 \mathrm{~mL}$ of ice-cold phosphate buffer (0.1 M; pH = 7.2) and homogenised (Ystral Homogeniser mod. D-7982) for $20 \mathrm{~s}$ at $c a .4^{\circ} \mathrm{C}$. The homogenate was immediately centrifuged at $5,000 \mathrm{~g}$ during 3 minutes at $4^{\circ} \mathrm{C}$.

\section{Enzymatic characterization}

The enzymatic characterisation was performed by studying the preferences of substrate of the enzyme present and its behaviour towards selective inhibitors, as described by Garcia et al (2000) but using a different temperature for enzymatic analysis. ChE activity at increasing concentrations of acetylthiocholine (ACT), butyrylthiocholine (BUT) and propionylthiocholine (PRO) (from 0.01 to $2.56 \mathrm{mM}$ ) was determined in independent experiments. Eserine sulphate, isoOMPA and 1,5-bis(4-allyldimethylammoniumphenyl)-pentan3-one dibromide (BW284C51) were used as selective inhibitors of ChE, PChE and AChE, respectively. For each inhibitor, enzymatic activity was determined with ACT after an incubation period of $30 \mathrm{~min}$ at $26 \pm 1{ }^{\circ} \mathrm{C}(8 \mu \mathrm{l}$ of a stock solution prepared in ethanol or ultra-pure water as appropriated was added to $492 \mu 1$ of $P$. reticulata homogenate). Controls were incubated with $8 \mu$ l of ultra-pure water and additional controls with ethanol were also included when appropriate.

\section{Effects of time and temperature sample preservation}

The effects of time and freezing temperature on the activity of wild $P$. reticulata $\mathrm{ChE}$ were determined in 48 samples prepared as above described for the characterisation study, using one fish head per sample. In nine samples, defined as the control group, ChE was immediately determined after the preparation of the homogenates. A group of twelve samples was maintained in a freezer $\left(-18^{\circ}\right.$ to $\left.-20^{\circ} \mathrm{C}\right)$, another group of twelve samples was kept in a deep freezer $\left(-48\right.$ to $\left.-51^{\circ} \mathrm{C}\right)$ and a third group of samples was kept in liquid nitrogen $\left(\mathrm{ca} .-196^{\circ} \mathrm{C}\right)$, during four consecutive weeks. After each week, ChE was determined in four samples of each group. 


\section{ChE and protein determinations}

ChE activity was determined by the method described in Ellman et al. (1961) adapted to microplate (Guilhermino et al., $1996 \mathrm{a}$ ), using $0.05 \mathrm{ml}$ of homogenate and $0.250 \mathrm{ml}$ of the reaction solution, at $414 \mathrm{~nm}$, at a temperature of $26.0 \pm 1^{\circ} \mathrm{C}$. The enzymatic activity was determined in quadruplicate and expressed as units

(U) per mg of protein ( $\mathrm{U}$ is $1 \mathrm{nmol}$ of substrate hydrolyzed per minute). Protein concentrations before and after the enzymatic analysis were determined in quadruplicate by the Bradford method (Bradford, 1976) adapted to microplate, using bovine Y-globulin as standard and a Labsystem Multiskan Ascent microplate reader. Protein was standardised to $0.3 \mathrm{mg} / \mathrm{ml}$ before $\mathrm{ChE}$ determinations.

\section{Range of ChE activity in wild fish}

The normal range of AChE activity of $P$. reticulata head was determined in 39 adult male fish collected in the Capivari Creek in different months of the year.

\section{Chemicals}

ACT, BUT, PRO, DTNB, and bovine $\gamma$-globulin were purchased from Sigma-Aldrich, the Bradford of protein assay reagent was bought from BIO-RAD and the remaining substances were acquired from MERCK.

\section{Data analysis}

Different treatments in the experiments with selective inhibitors were compared using one-way Analysis of Variance (ANOVA) and the effects of time and temperature of sample storage were determined using a two-way ANOVA, followed by a Dunnet's test (Zar, 1996). No-observed effect concentration (NOEC) and the lowest observed effect concentration (LOEC) were determined by the Dunnet multicomparison test. $\mathrm{IC}_{50}$ values were calculated by the Probit Analysis (Finney, 1971). Significant difference was accepted at $p<0.05$.

\section{RESULTS}

ChE activity of $P$. reticulata's head as a function of increasing concentrations of ACT, BUT and PRO is showed in Figure 1. The maximum activity $(109.68 \pm 3.23 \mathrm{SE} \mathrm{U} / \mathrm{mg}$ protein) was obtained with ACT at $1.28 \mathrm{mM}$ and inhibition of ChE activity was observed at the highest ACT concentration tested $(2.56 \mathrm{mM})$. Lower activities were obtained with PRO $(59.04 \pm 9.5 \mathrm{SE} \mathrm{U} / \mathrm{mg}$ protein at $1.28 \mathrm{mM})$ and BUT $(40.53 \pm$ $14.03 \mathrm{SE} \mathrm{U} / \mathrm{mg}$ protein at $1.28 \mathrm{mM})$.

Eserine sulphate $(\mathrm{F}=100.65 ; p<0.05$; Figure 2$)$ and $\mathrm{BW} 284 \mathrm{C} 51(\mathrm{~F}=70.597 ; p<0.05$; Figure 3$)$ significantly inhibited $\mathrm{ChE}$ activity. Inhibition was almost complete with $25.6 \mu \mathrm{M}$ of eserine sulphate (96.7\%) and with $25.6 \mu \mathrm{M}$ of BW284C51 (95.3\%)

(Figures 2 and 3). $\mathrm{IC}_{50[30 \mathrm{~min}]}$ for eserine sulphate and BW284C51 were $0.16 \propto \mathrm{M}$ and $1.04 \propto \mathrm{M}$, respectively. LOECs for these compounds were similar $(0.1 \propto \mathrm{M})$ (Table 1). LOECs for these compounds were similar $(0.1 \propto \mathrm{M})$ (Table 1$)$. Soluble ChE from $P$. reticulata head was relatively insensible to iso-OMPA since no significant difference was observed at final concentrations up to $128 \propto \mathrm{M}(\mathrm{F}=0.5676 ; p>0.05 ;$ Figure 4$)$.

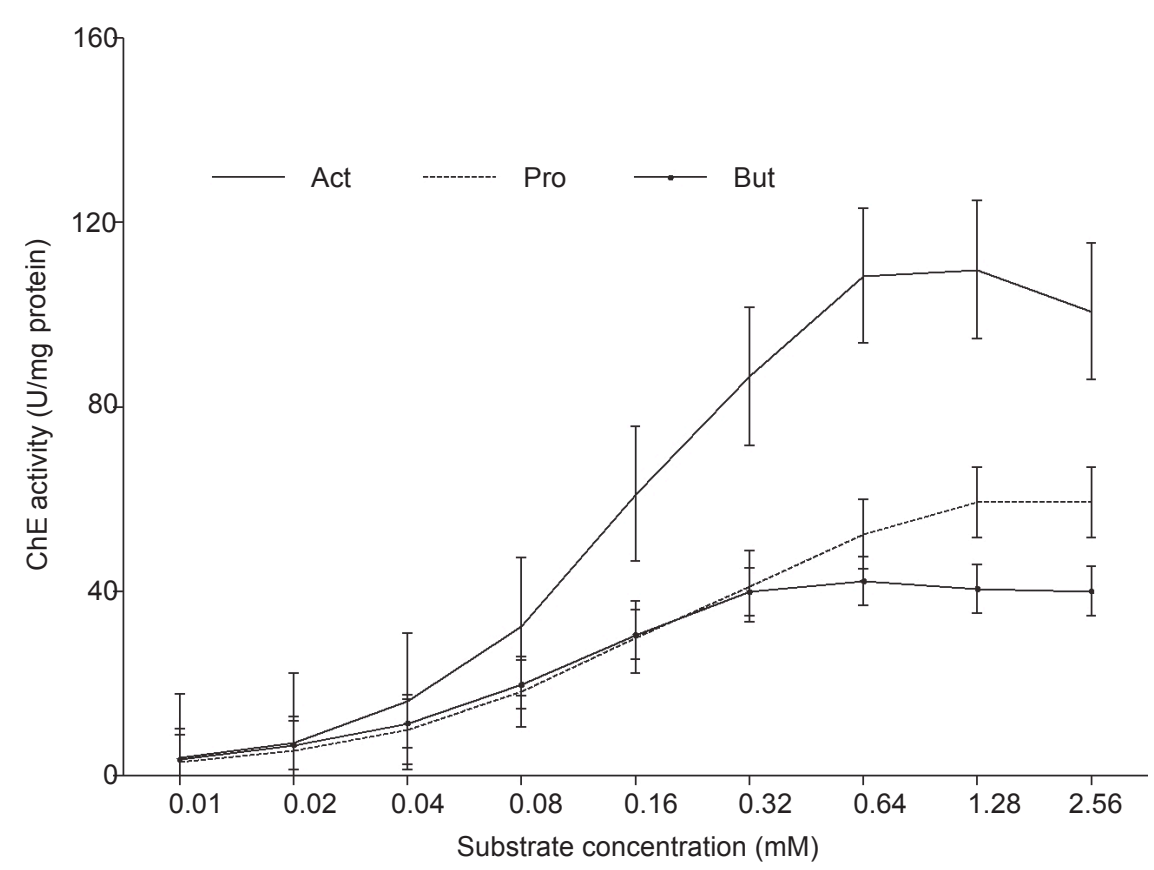

Figure 1 - Cholinesterase (ChE) activity in the head of $P$. reticulata as function of acetylthiocholine (Act), butyrylthiocholine (But) and propionylthiocholine (Pro) concentration. Values are the mean of 12 enzymatic determinations per 3 replicate. 


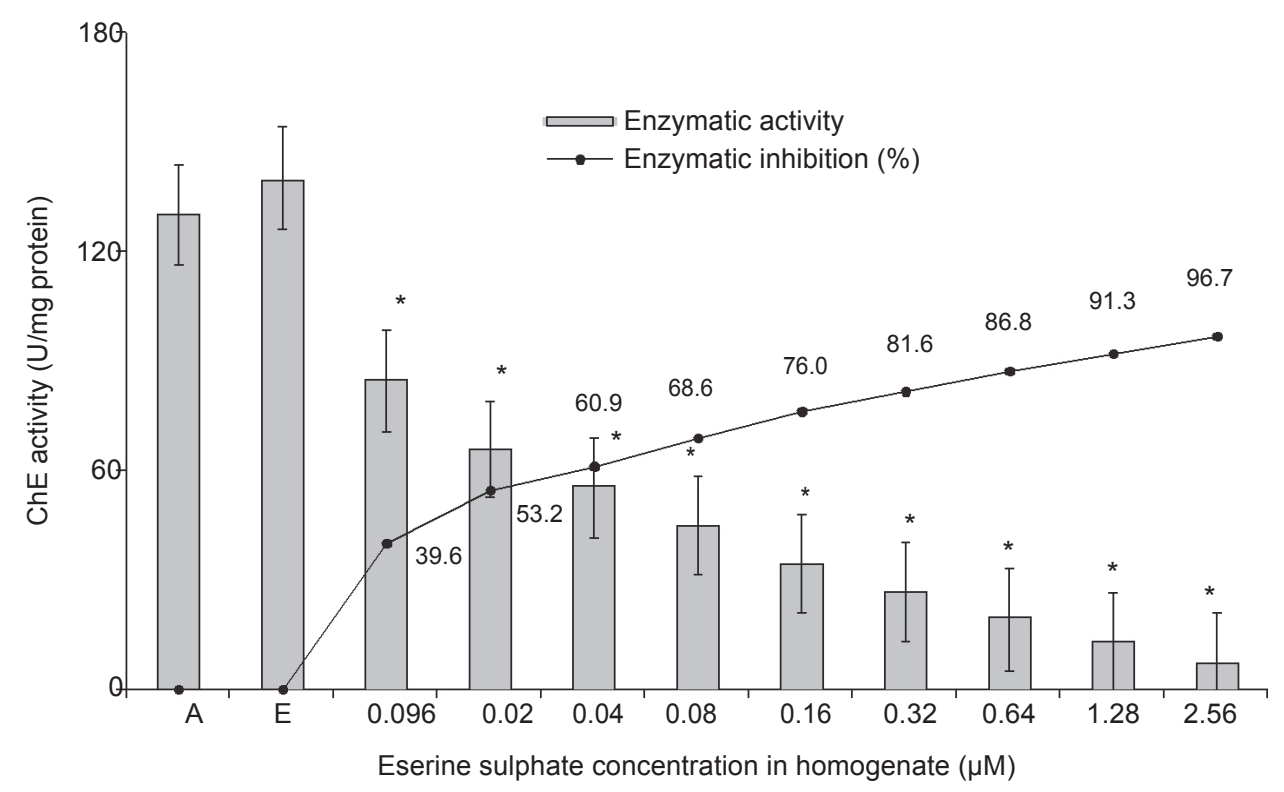

Figure 2 - Effect of eserine sulphate on cholinesterase $(\mathrm{ChE})$ activity in the head of $P$. reticulata (wild organisms). Values are the mean of 12 enzymatic determinations per 3 replicate and corresponding standard error bars. $\mathrm{A}=$ distilled water control; $\mathrm{E}=\mathrm{ethanol}$ control. Asterisk indicates a statistical significance from the control group after one-way ANOVA $(p<0.05)$.

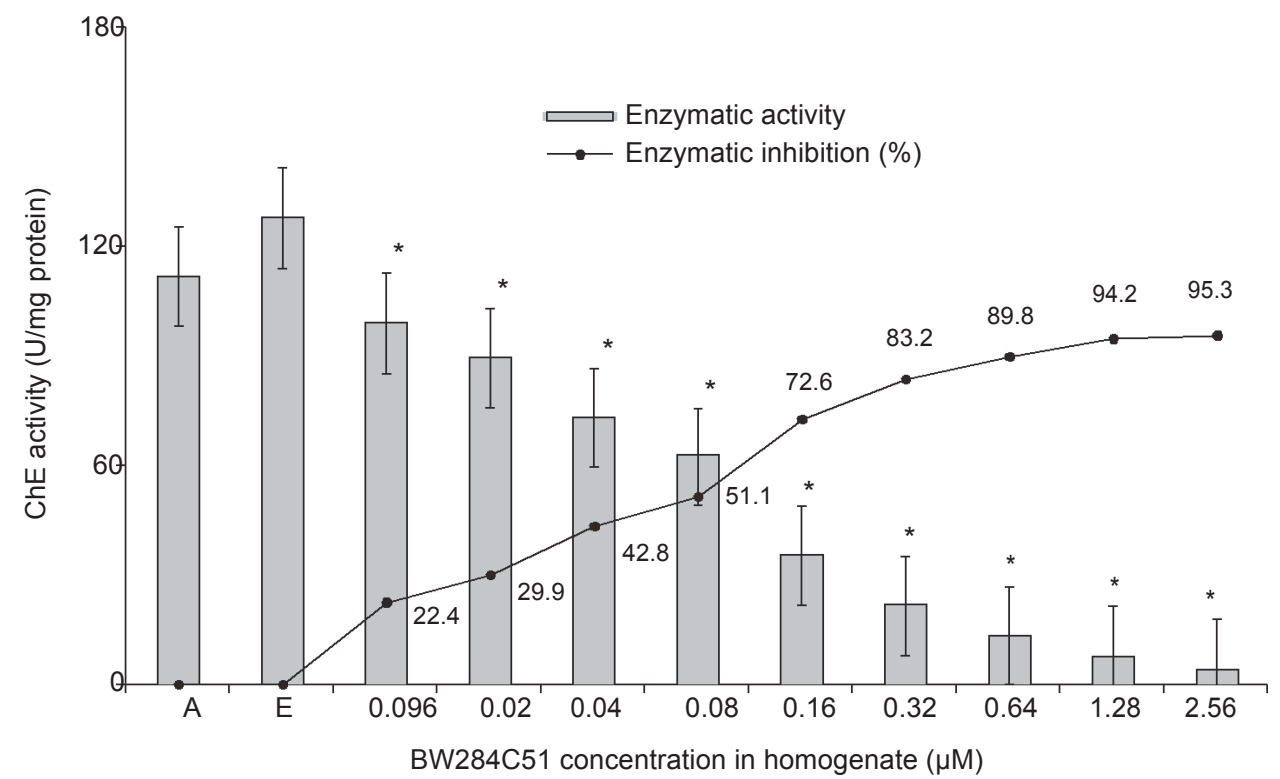

Figure 3 - Effect of BW284C51 on cholinesterase (ChE) activity in the head of P. reticulata (wild organisms). Values are the mean of 12 enzymatic determinations per 3 replicate and corresponding standard error bars. $\mathrm{A}=$ distilled water control; $\mathrm{E}=$ ethanol control. Asterisk indicates a statistical significance from the control group after one-way ANOVA $(p<0.05)$.

Regarding the effect of storage on $P$. reticulata homogenates, the values of AChE activity measured during four (4) weeks were different statistically and can be identified through the $\left.{ }^{*}\right)$ mark in Figure $5(p<0.05)$. During the first week of storage, the value of AChE activity stored in liquid-N was higher $(155.55 \pm 5.45$ $\mathrm{SE} \mathrm{U} / \mathrm{mg}$ protein; $\mathrm{F}=6.555 ; p<0.05$ ) to that kept in freezer $-20^{\circ} \mathrm{C}$ (131.01 $\pm 1.36 \mathrm{SE} \mathrm{U/mg} \mathrm{protein);} \mathrm{however,} \mathrm{it} \mathrm{did} \mathrm{not} \mathrm{differ}$ from the enzyme activity measured in controls (135.73 \pm $3.81 \mathrm{SE} \mathrm{U} / \mathrm{mg}$ protein). Values for the enzymatic activities during four weeks of storage under all temperatures were different from the control and other storage periods.

The range of ChE activity in male fish collected in different periods of the year was $149.71 \pm 7.72 \mathrm{SD}$ U/mg protein measure in 156 enzymatic repetitions. 
Table 1 - Effect of specific inhibitors on AChE of $P$. reticulata brain. NOEC - no observed effect concentration, LOEC - lowest observed effect concentration, $\mathrm{IC}_{50}-50 \%$ inhibition concentration, $95 \%$ confidence limits are shown within parentheses.

\begin{tabular}{lccc}
\hline Inhibitor & NOEC $(\propto \mathbf{M})$ & LOEC $(\propto \mathbf{M})$ & IC $50\left[30\right.$ min.] $_{(}(\propto \mathbf{M})$ \\
\hline Eserine sulphate & $<0.1$ & 0.1 & 0.16 \\
Iso-OMPA & 128.0 & $*$ & $(0.10-0.28)$ \\
BW284C51 & $<0.1$ & 0.1 & $*$ \\
& & & $(0.04$ \\
\hline
\end{tabular}

*No significant inhibition was found up to $128.0 \propto \mathrm{M}$.

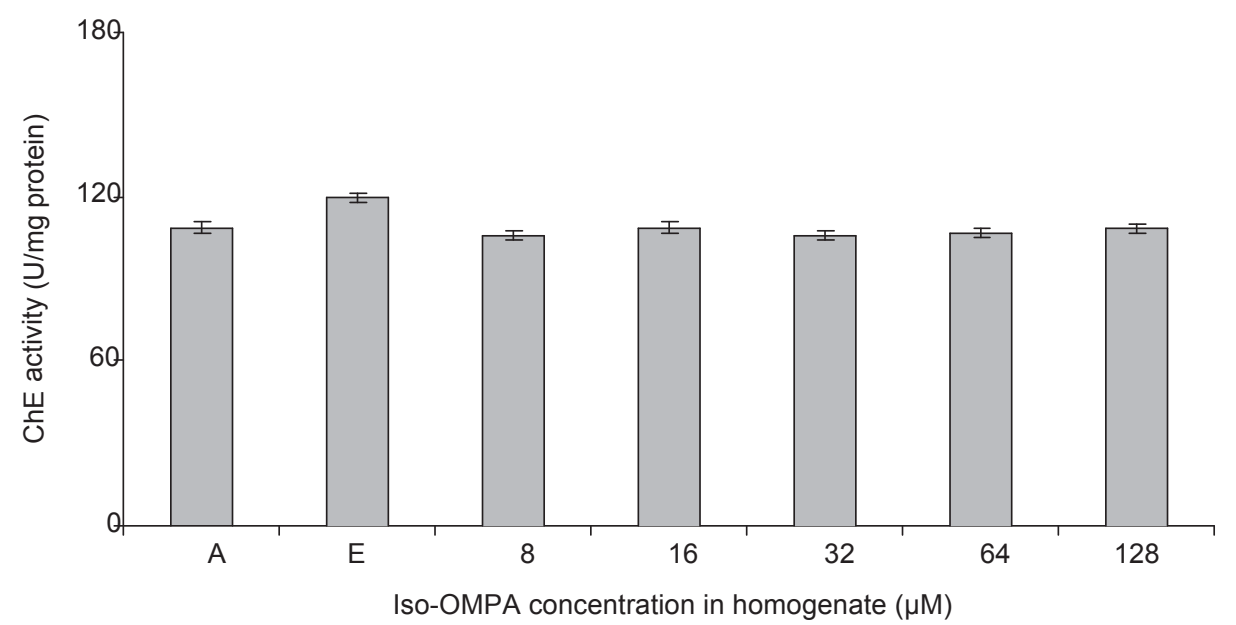

Figure 4 - Effect of iso-OMPA on cholinesterase (ChE) activity in the head of $P$. reticulata (wild organisms). Values are the mean of 12 enzymatic determinations per 3 replicate and corresponding standard error bars. $\mathrm{A}=$ distilled water control; $\mathrm{E}=$ ethanol control.

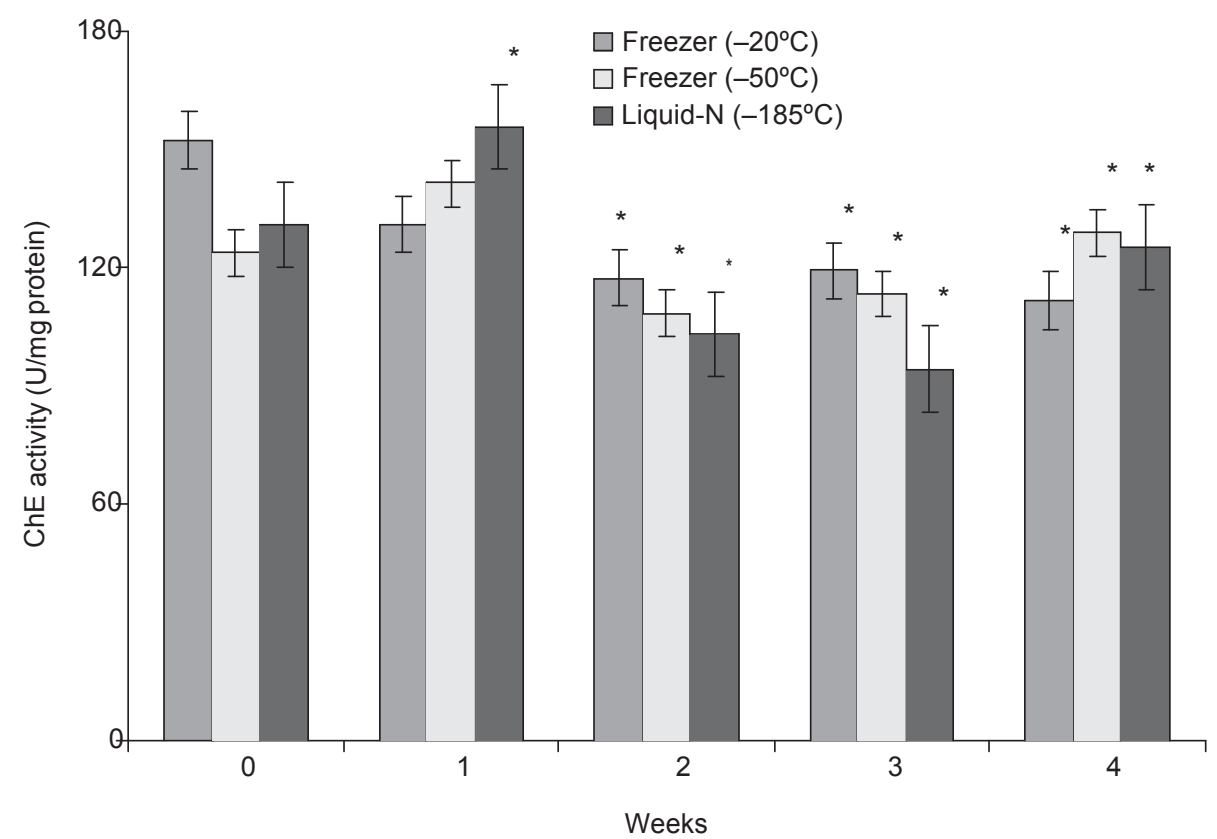

Figure 5 - Acetylcholinesterase (AchE) activity in different temperature and period of storage for 4 weeks.

Values are the mean of 12 enzymatic determinations per 3 replicate and corresponding standard error bars. Asterisk indicates a statistical significance from the 0 week group after two-way ANOVA $(p<0.05)$, followed by a Dunnet's test. 


\section{DISCUSSION}

The almost full inhibition of $P$. reticulata enzymatic activity by eserine sulphate suggests that the activity measured is of $\mathrm{ChE}$ and no significant amounts of no-specific esterases were present in the fraction analyzed. The preference of head for ACT over BUTC and PCT, the inhibition by excess of substrate, the high sensitivity to $\mathrm{BW} 284 \mathrm{C} 51$ and the relative insensitivity to iso-OMPA indicates that the predominant enzymatic form in the soluble fraction of wild $P$. reticulata head was AChE. This result is in good agreement with the results obtained by Rendón-von Osten et al. (unpublished results) which indicated that the main $\mathrm{ChE}$ form in head homogenates of commercial P. reticulata head was indeed AChE. Moreover, the data provided here is in good agreement with the findings reported in the literature for other species of Teleostei fish (Garcia et al., 2000; Rendón-von Osten et al., 2005; Szegletes et al., 1995; Sturm et al., 2000). Since different populations of the same species may show genetic variability in what concerns $\mathrm{ChE}$ forms, the good agreement between the results obtained with commercial and wild fish is particular important since it enables the comparison of wild populations responses to environmental contaminants with those of commercially available fish for which a considerable amount of data already exist and solves one of the main problems of biomonitoring studies using native populations, that is the lack of suitable reference values (Rendón-von Osten et al., 2006). It also makes ecological relevant the use of commercial fish in some ecotoxicological studies as substitute of wild fish without the need of extrapolations with ethical advantages.

The sample storage is an important technical procedure frequently used when the number of samples is considerably high. However, some precaution should be taken when using organisms and tissues not used before in the laboratory because some storage conditions may significantly decrease the $\mathrm{ChE}$ activity in the samples. In this study, samples stored up to one week at -18 to $-20,-48$ to $-51^{\circ} \mathrm{C}, \mathrm{ca} .-196^{\circ} \mathrm{C}$ did not show significant alterations relatively to $\mathrm{ChE}$ activity determined in fresh samples. However, after two weeks of freezing at these temperatures, a significant decrease of $\mathrm{ChE}$ activity was observed. This results are in disagreement with the results found for D. magna where no significant decrease was observed up to forty days of freezing both a -20 and at $-70^{\circ} \mathrm{C}$ (Guilhermino et al., 1996b). These evidences may suggest that the loss of activity may depend of the species, tissue or the homogenate preparation (e.g. buffer, $\mathrm{pH}$ ).

The enzymatic activity reduction in homogenates stored at $-20^{\circ} \mathrm{C}$ for the first week in comparison to samples stored at $196^{\circ} \mathrm{C}$ can represent specific alterations of enzymes selected by tissue to compensate changes during the storage of the organ (Cowan \& Storey, 2001). These authors indicate that changes in the enzymatic activity in vitro can be related with covalent modifications or with proteic reverse phosphorilation. These molecular alterations may induce loss of enzymatic activity of small frozen quantity of enzymes under $-20{ }^{\circ} \mathrm{C}$ compared to those stored at $-196^{\circ} \mathrm{C}$.
As the experiments were independent, the increase from the enzymatic activity observed in samples of $P$. reticulata's head stored to the $-196^{\circ} \mathrm{C}$ can be related with the population normal variability (Fossi \& Leonzio, 1994).

ChE activity for wild $P$. reticulata's head obtained in this study $(149.71 \pm 1.93 \mathrm{U} / \mathrm{mg}$ protein) is higher than the correspondent activity determined in commercial $P$. reticulata head $(70 \pm 6.82 \mathrm{U} / \mathrm{mg}$ protein) (Rendón-von Osten et al., unpublished results). However, these authors performed $\mathrm{ChE}$ determinations at $25^{\circ} \mathrm{C}$ while a temperature of $30^{\circ} \mathrm{C}$ was used in this study. Since ChE activity measurements may be affected by temperature (Galgani \& Bocquené, 1990), this may contributed to the differences of activity between these two studies. Our results are close to those obtained by Garcia et al. (2000), that measured a ChE activity of $145.1 \pm 44.7 \mathrm{U} / \mathrm{mg}$ protein in $P$. reticulata muscle, and higher than the values reported at lower temperatures for other fish species. For example, an activity of $7.95 \mathrm{U} / \mathrm{mg}$ protein was found in Cyprinus carpio brain (Szegletes et al., 1995), while 80-90 $\mathrm{U} / \mathrm{mg}$ protein were found for Pomatoschistus microps head (Monteiro et al., 2006; Vieira et al., 2008) and $85.5 \mathrm{U} / \mathrm{mg}$ protein were found for Serranus cabrilla (Sturm et al., 1999). It should be mentioned, however, that $\mathrm{ChE}$ activities may also vary with fish size, as Flammarion et al. (2002) observed, with the larger fish having the lower $\mathrm{ChE}$ activities.

In conclusion, the results of this study indicate that the predominant form present in the soluble fraction of head homogenates from wild $P$. reticulata collected in the region of Cruz das Almas (Bahia, Brazil) is AChE, the mean activity in the population studied is $149.71 \pm \mathrm{U} / \mathrm{mg}$ and the samples may be frozen at $-20,-50$ or $-196^{\circ} \mathrm{C}$ up to seven days before loosing activity. Furthermore, since a good agreement between the results obtained with wild and commercially available $P$. reticulata was obtained, the results of biomonitoring studies and in situ tests using $\mathrm{ChE}$ as a biomarker may be compared with the responses obtained in laboratorial and/or field tests with commercial fish.

Acknowledgements - This research was financed by the European Union (INCO-program: TROCA-WET project, ref. ERBIC18-CT98-0264) and by the bi-lateral cooperation Portugal/Brazil (ICCTI/CNPq-program: BIOMARCADORES project). E. M. da Silva acknowledges receiving a grant from the National Council of Scientific and Technological Development (CNPq).

\section{REFERENCES}

BAUMANS, V., 2005, Science-based assessment of animal welfare: laboratory animals. Rev. Sci. Tech. Off. Int. Epiz., 24: 503-514.

BRADFORD, M., 1976, A rapid and sensitive method for quantification of microgram quantities of protein utilizing the principle dye binding. Anal. Biochemistry, 72: 248-254.

COWAN, K. J. \& STOREY, K. B. M., 2001, Freeze-thaw effects on metabolic enzymes in wood frog organs. Cryobiology, 43: 32-45.

DAY, K. \& SCOTT, I. M., 1990, Use of acetylcholinesterase activity to detect sublethal toxicity in stream invertebrates exposed to low concentrations of organophosphate insecticides. Aquatic Toxicol., 8: 101-114. 
ELLMAN, G. L. et al., 1961, A new and rapid colorimetric determination of acetylcholinesterase activity. Bioch. Pharm., 7: 88-95.

ETO, M., 1974, Organophosphorus pesticides: organic and biological chemistry. CRS Press, Boca Raton, 196p.

FINNEY, D. J., 1971, Probit analysis. Cambridge University Press, Cambridge, $333 \mathrm{p}$.

FLAMMARION, P., NOURY, P. \& GARRIC, J., 2002, The measurement of cholinesterase activities as a biomarker in chub (Leuciscus cephalus): the fish length should not be ignored. Environ. Pollut., 120: 325-330.

FOSSI, M. C. \& LEONZIO, C., 1994, Non destructive biomarkers in vertebrates. Lewis Publishers, Boca Raton.

FOSSI, M. C., MINUTOLI, R. \& GUGLIELMO, L., 2001, Preliminary results of biomarker responses in zooplankton of brackish environments. Marine Pollut. Bull., 42: 745-748.

FRASCO, M. F. \& GUILHERMINO, L., 2002, Effects of dimethoate and beta-naphthoflavone on selected biomarkers of Poecilia reticulata. Fish Physiol. Biochem., 26: 149-156.

FULTON, M. H. \& KEY, V., 2001, Acetylcholinesterase inhibiton in estuarine fish and invertebrates as an indicator of organophosphorus insecticide exposure and effects. Environ. Tox. Chem., 20: 37-45.

GALGANI, F. \& BOCQUENÉ, G., 1990. In vitro inhibition of acetylcholinesterase from four marine species by organophosphates and carbamates. Bull. Environ. Contam. Toxicol., 45: 243-249.

GARCIA, A. et al., 2000, Characterization of cholinesterases from guppy (Poecilia reticulata) muscle and its inhibition by environmental contaminants. Biomarkers, 5: 274-284.

GUILHERMINO, L. et al., 1996a, Inhibition of acethylcholinesterase activity as effect criterion in acute tests with juvenile Daphnia magna. Chemosphere, 32: 727-738.

GUILHERMINO, L. et al., 1996b, Acetylcholinesterase activity in juveniles of Daphnia magna Straus. Bull. Environ. Contam. Toxicol., 57: 979-985.

MONTEIRO, M. et al., 2006, Acute effects of 3,4-dichloroaniline on biomarkers and spleen histology of the common goby Pomatoschistus microps. Chemosphere, 62: 1333-1339.

OECD, 1993, OECD Guideline for the testing of chemicals. Test 203: Fish, acute toxicity test. Organisation for Economic Cooperation and Development, Paris.
OZMEN, M., SENER, S., METE, A. \& KUCUKBAY, H., 1999, In vitro and in vivo acetylcholinesterase inhibition effect of new classes of organophosphorus compounds. Environ. Tox. Chem., 18: 241-246.

RENDÓN-VON OSTEN, J., MEMIJE, M. G., ORTIZ, A., SOARES, A. M. V. M. \& GUILHERMINO, L., 2006, An integrated approach to assess water quality and environmental contamination in the fluvial lagoon system of the Palizada River, Mexico. Environ. Tox. Chem., 25: 3024-3034.

RENDÓN-VON OSTEN J., ORTIZ-ARANA, GUILHERMINO, L. \& SOARES, A. M. V. M., 2005, In vivo evaluation of three biomarkers in the mosquitofish (Gambusia yucatana) exposed to pesticides. Chemosphere, 58: 627-636.

STOJAN, J., MARCEL, V., ESTRADA-MONDACA, S., KLAEBE, A., MASSON, P. \& FOURNIER, D., 1998, A putative kinetic model for substrate metabolisation by Drosophila acetylcholinesterase. FEBS Letters, 440: 85-88.

STURM, A., WOGRAM, J., HANSEN, P. D. \& LIESS, M., 1999. Potential use of cholinesterase in monitoring low levels of organophosphates in small streams: natural variability in three-spined stickleback (Gasterosteus aculeatus) and relation to pollution. Environ. Tox. Chem., 18: 194-200.

STURM, A. et al., 2000, Different sensitivity to organophosphates of acetylcholinesterase and butyrylcholinesterase from three-spined stickleback (Gasterosteus aculeatus): application on biomonitoring. Environ. Tox. Chem., 19: 1607-1617.

SZEGLETES, T. et al., 1995, In vivo effects of deltamethrin exposure on activity and distribution of molecular forms of carp AChE. Ecotox. Environ. Saf., 31: 258-263.

VIEIRA, L.R., SOUSA, A., FRASCO, M. F., LIMA, I., MORGADO, F. \& GUILHERMINO, L., 2008, Acute effects of Benzo[a]pyrene, anthracene and a fuel oil on biomarkers of the common goby Pomatoschistus microps (Teleostei, Gobiidae). Sci. Total Environ., 395: $87-100$.

ZAR, J. H., 1996, Biostatistical analysis. Prentice Hall International Editions, London, Third Ed., 662p. 